\title{
Cell-wall-bound lytic activity in Chlorella fusca: function and characterization of an endo-mannanase
}

\author{
E. Loos and D. Meindl \\ Institut für Botanik, Universität Regensburg, Universitätsstrasse 31, D-8400 Regensburg, Federal Republic of Germany
}

\begin{abstract}
A cell-wall-degrading activity was solubilized from young cells and from mother cell walls of Chlorella fusca by treatment with $\mathrm{LiCl}$. The cytoplasmic enzyme hexokinase was not detectable in these extracts. The LiCl-solubilized activity increased in the cell cycle parallel to the release of autospores. The enzyme was purified on a chromatofocusing column followed by gel filtration. Sodium dodecyl sulfate/polyacryl amide gel electrophoresis of the purified enzyme revealed a molecular weight of $44 \mathrm{kDa}$, whereas gel filtration indicated a molecular weight of $25 \mathrm{kDa}$. Cell-wall-lytic activity and $\beta$-1,4-mannanase activity coeluted in gel filtration and were separated from $\beta$-D-fucosidase activity. The enzyme degraded isolated cell walls and ivory nut mannan primarily to oligosaccharides with an estimated degree of polymerization $\geqq 6$. The soluble degradation products of the cell wall consisted of $92-96 \%$ mannose and $4-8 \%$ glucose. It is concluded that the cell-wall-lytic activity is caused by an endo-mannanase. In vivo, this enzyme probably degrades the mother cell wall and, after autospore release, remains bound to it as well as to the surface of the daughter cells by ionic forces. The identity of this bound enzyme with a soluble wall-degrading enzyme previously obtained from mother cells is discussed.
\end{abstract}

Key words: Cell cycle - Cell wall (lysis) - Chlorella (cell wall) - Endo-mannanase.

\section{Introduction}

A cell-wall-degrading activity appears in homogenates of Chlorella shortly before release of the daughter cells (autospores); it is probably essential for opening the mother cell wall. During the period of hatching this lytic activity decreases (Loos and Meindl 1984). Since it could not be recovered from the culture medium, it was assumed that the lytic activity eventually became bound to the opened mother cell wall and/or to the surface of the daughter cells (Loos and Meindl 1984). One goal of this work was to test this assumption using $\mathrm{LiCl}$ for enzyme solubilization, a salt which has effectively been used for removal of wall-bound hydrolases in Streptococcus faecalis and Zea mays (Pooley et al. 1970; Huber and Nevins 1981). Another goal was, in this way, to obtain the enzyme(s) without the many soluble proteins, thus simplifying purification and characterization.

\section{Material and methods}

Plant material. Chlorella fusca Shihira et Krauss strain 211-8b was obtained from Sammlung für Algenkulturen, Göttingen, FRG. The algae were grown in the medium described by Kuhl (1962); they were synchronized by a $14 \mathrm{~h}$ light $(8000 \mathrm{~lx}) / 10 \mathrm{~h}$ dark regime. Other conditions of culture were as reported previously (Loos and Meindl 1982).

Separation of mother cell walls from daughter cells. A culture with young cells ( $24 \mathrm{~h}$ after start of the light phase) was harvested, suspended in fresh nutrient medium containing $50 \%$ Percoll by volume (Pharmacia, Freiburg, FRG) at a cell density of $1.8 \cdot 10^{8} \mathrm{ml}^{-1}$ and centrifuged in a Sorvall SS 34 Rotor (Dupont Instr., Bad Nauheim, FRG) at $48000 \mathrm{~g}$ for $30 \mathrm{~min}$.

Enzyme purification and gel electrophoresis. A culture with young cells was harvested, suspended in fresh nutrient medium containing $50 \%$ Percoll $(\mathrm{v} / \mathrm{v})$ at a cell density of $30 \cdot 10^{9} \mathrm{ml}^{-1}$, made $0.2 \mathrm{~mol} \cdot \mathrm{1}^{-1}$ with respect to $\mathrm{LiCl}$ and incubated for $10 \mathrm{~min}$. Percoll and the algal material were then removed by centrifugation $(100000 \mathrm{~g}, 2 \mathrm{~h})$, the supernatant was concentrated by ultrafiltration (YM5 membrane, Amicon, Witten, FRG) and applied to a Bio-Gel P-100 column (Bio-Rad Labor., München, FRG; length $103 \mathrm{~cm}$, diameter $1.5 \mathrm{~cm})$. The column was eluted with $0.02 \mathrm{~mol} \cdot 1^{-1} 2$-( $\mathrm{N}$-morpholino)ethanesulfonic acid (MES)-KOH buffer ( $\mathrm{pH} 6.2$ ) containing $0.05 \mathrm{~mol} \cdot \mathrm{l}^{-1} \mathrm{KCl}$ and $0.02 \% \mathrm{NaN}_{3}$; fractions of $3 \mathrm{ml}$ were collected. For highly purified enzyme preparations the gel filtration step was preceded by a run on a chromatofocusing column. In this case the ultrafiltrate was dialyzed against $0.025 \mathrm{~mol}^{-1} \mathrm{l}^{-1}$ ethanolamine buffer ( $\mathrm{pH} 9.4$ ), applied to a chromatofocusing column 
(length $24.0 \mathrm{~cm}$, diameter $0.6 \mathrm{~cm}$ ) filled with exchanger gel PBE 94 and was eluted with $100 \mathrm{ml}$ Polybuffer 96, pH 7.0 (Pharmacia, Freiburg, FRG); fractions of $5 \mathrm{ml}$ were collected. The two most active fractions were concentrated by ultrafiltration and applied to the gel filtration column as above. All operations after harvest of the algae were carried out at $0-4^{\circ} \mathrm{C}$. Usually batches of $7-10 \cdot 10^{10}$ cells were processed. Sodium dodecyl sulfate/polyacrylamide gel electrophoresis was carried out on slab gels (10\% polyacrylamide) essentially according to King and Laemmli (1971); incubation in the sample buffer was overnight at $4^{\circ} \mathrm{C}$. Protein bands were fixed and visualized with a silver stain (Morrisey 1981).

Tests for enzymatic activities, analysis of degradation products and protein determination. Hexokinase activity was measured in a spectrophotometric test by following at $340 \mathrm{~nm}$ the reduction of NADP coupled to the oxidation of glucose-6-phosphate. The assay mixture contained $0.38 \mathrm{mmol} \cdot 1^{-1}$ triethanolamine buffer ( $\mathrm{pH} 7.6$ ), $5.2 \mathrm{mmol} \cdot 1^{-1} \mathrm{MgCl}_{2}, 1.1 \mathrm{mmol} \cdot 1^{-1}$ mercaptoethanol, $0.53 \mathrm{mmol} \cdot 1^{-1}$ ATP, $0.36 \mathrm{mmol} \cdot 1^{-1} \mathrm{NADP}, 0.45 \mathrm{U}$. $\mathrm{ml}^{-1}$ glucose-6-phosphate dehydrogenase (Boehringer, Mannheim, FRG) and the soluble fraction of a LiCl-containing cell homogenate or a $\mathrm{LiCl}$ extract from an intact algal culture, both introducing $\mathrm{LiCl}$ to a final concentration of $0.03 \mathrm{~mol} \cdot 1^{-1}$ and material from $4 \cdot 10^{8}$ cells per $\mathrm{ml}$ assay mixture; the reaction was started by addition of glucose $\left(50 \mu \mathrm{g} \cdot \mathrm{ml}^{-1}\right) . \beta$-D-Fucosidase was tested with $p$-nitrophenyl- $\beta$-D-fucopyranoside according to Walter (1984). Tests for cell-wall-lytic activity and $\beta$-1,4D-mannanase contained $0.016 \mathrm{~mol} \cdot 1^{-1}$ MES-KOH buffer (pH 6.2), $1 \mathrm{mmol} \cdot 1^{-1} \mathrm{CaCl}_{2}, 0.02 \% \mathrm{NaN}_{3}$ and isolated cell walls or mannan from ivory nut at $2 \mathrm{mg} \cdot \mathrm{ml}^{-1}$; other conditions and details have been described (Loos and Meindl 1984). After incubation the carbohydrate content in the supernatant of a centrifuged sample was determined with the phenol-sulphuric acid method with mannose as reference (Dubois et al. 1956). For analysis of the degradation products the supernatant was kept for $3 \mathrm{~min}$ at $100^{\circ} \mathrm{C}$, desalted by a mixed-bed exchange resin and concentrated under reduced pressure. Samples equivalent to $40 \mu \mathrm{g}$ carbohydrate were applied to silica gel sheets and developed twice in acetone: $n$-butanol: $\mathrm{H}_{2} \mathrm{O}=70: 15: 15$ (by vol.). Staining for sugars was done with a diphenylamine-aniline reagent. Hydrolysis of the products of cell wall lysis was achieved with $2 \mathrm{~mol} \cdot \mathrm{1}^{-1}$ trifluoroacetic acid $\left(120^{\circ} \mathrm{C}, 2 \mathrm{~h}\right)$. The resulting monosaccharides were analyzed by gas liquid chromatography as described previously (Blumreisinger et al. 1983). Protein was assayed after hydrolysis $\left(6 \mathrm{~mol} \cdot \mathrm{l}^{-1} \mathrm{HCl}, 20 \mathrm{~h}\right.$, $105^{\circ} \mathrm{C}$ ) using a ninhydrin-based colorimetric method with leucine as reference (Moore 1968).

\section{Results}

Solubilization of cell-wall-lytic activity; appearance in the cell cycle. When freshly hatched daughter cells were incubated in the presence of $\mathrm{LiCl}$, cellwall-lytic activity was brought into solution (Table 1). At a concentration of $0.2 \mathrm{~mol} \cdot 1^{-1} 70 \%$ of the maximal value was attained. For all further experiments a concentration of $0.2 \mathrm{~mol} \cdot 1^{-1} \mathrm{LiCl}$ was used to solubilize the cell-wall-degrading activity.

To see whether the lytic activity could be involved in the liberation of the daughter cells, cultures from different developmental stages were
Table 1. Cell-wall-lytic activities from Chlorella fusca solubilized by different concentrations of $\mathrm{LiCl}$. A synchronized culture of young cells ( $24 \mathrm{~h}$ after onset of the light phase) was centrifuged, suspended to a cell density of $6.4 \cdot 10^{8} \mathrm{ml}^{-1}$ in fresh nutrient medium containing the desired concentration of $\mathrm{LiCl}$ and was incubated for $10 \mathrm{~min}$. After centrifugation the resulting supernatant was dialyzed against $0.02 \mathrm{~mol} \cdot 1^{-1}$ MES-KOH buffer ( $\mathrm{pH}$ 6.2) containing $0.02 \% \mathrm{NaN}_{3}$ and tested for cell-walllytic activity. Except for the initial harvesting, all operations were carried out at $0-4^{\circ} \mathrm{C}$. The maximum activity corresponded to $9.4 \cdot 10^{-13} \mathrm{~g}$ carbohydrate $\cdot \mathrm{h}^{-1}$ per cell

\begin{tabular}{ll}
\hline $\begin{array}{l}\text { Concentration of } \\
\mathrm{LiCl}\left(\mathrm{mol} \cdot \mathrm{1}^{-1}\right)\end{array}$ & $\begin{array}{l}\text { Cell-wall-lytic } \\
\text { activity, } \mathrm{A}_{490}\end{array}$ \\
\hline 0 & 0.030 \\
0.05 & 0.052 \\
0.2 & 0.398 \\
0.5 & 0.520 \\
1.0 & 0.565 \\
\hline
\end{tabular}

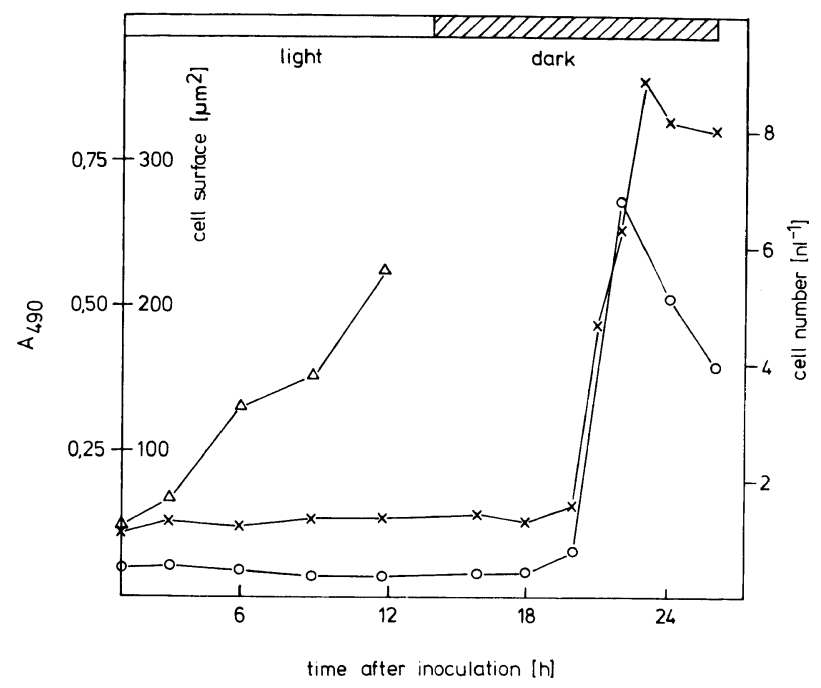

Fig. 1. Cell-wall-lytic activity solubilized by $\mathrm{LiCl}$ during the cell cycle of Chlorella fusca. The procedure for obtaining cellwall-lytic activity was as described in the legend to Table 1 , the concentration of $\mathrm{LiCl}$ employed was $0.2 \mathrm{~mol} \cdot \mathrm{l}^{-1}$. Cell number $(\mathrm{x}-\mathrm{x})$; cell-wall lysis $(\mathrm{O}-\mathrm{O})$; cell surface $(\Delta-\Delta)$

subjected to the $\mathrm{LiCl}$ treatment and tests were made for cell-wall-lytic activity. As shown in Fig. 1, a sharp increase occurred parallel to the release of the autospores. This observation agrees with the idea that the lytic activity was bound to the inside of the mother cell wall and/or to the surface of the young cells. The decline in activity after hatching was less pronounced in another experiment and could have been the result of a slow dissociation of the enzyme(s) from the cell walls and cells.

To find out whether or not the salt treatment caused a substantial leakage of cytoplasmic enzymes from the young cells into the medium, tests 


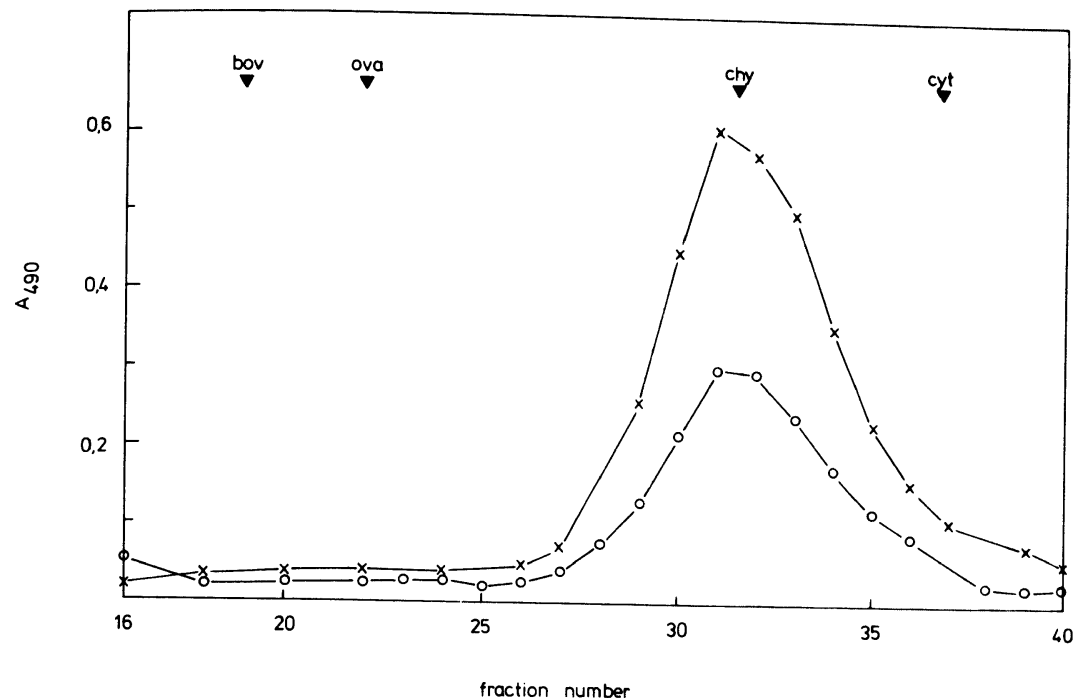

Fig. 2. Gel filtration of cell-wall-lytic activity derived from young cells $\left(x-\frac{x}{x}\right)$ and mother cell walls ( $0-0)$. After recovery from the Percoll gradient the cell fraction and the wall fraction were treated with $\mathrm{LiCl}\left(0.2 \mathrm{~mol} \cdot 1^{-1}\right)$ and further processed as described under Material and methods. At the top are indicated the positions of marker proteins from test runs; $b o v=$ bovine serum albumin, ova $=$ ovalbumin; $c h y=$ chymotrypsinogen, $c y t=$ cytochrome $\mathrm{c}$ were made for hexokinase activity in the $\mathrm{LiCl}$ extract and in the soluble fraction from a Frenchpress homogenate, also obtained in the presence of LiCl. Only in the latter case could hexokinase activity be detected and this was easily measurable (rates up to $0.027 \mathrm{~mol} \cdot \mathrm{h}^{-1} \cdot \mathrm{g}^{-1}$ protein). This is further evidence that the cell-wall-degrading activity was solubilized by $\mathrm{LiCl}$ not from the cytoplasm, but rather from the surfaces of the cells and/or mother cell walls.

Lytic enzymes have been considered to play a role in cell wall synthesis (Matile 1975). This does not seem to be the case with the LiCl-solubilized activity, since it stays at a constant level during the phase of active cell surface enlargement (Fig. 1). Therefore, it may well be responsible for the lysis of the mother cell wall.

Distribution of cell-wall-lytic activity between daughter cells and mother cell walls; gel filtration characteristics. To find out whether the cell-walllytic activity was localized on the opened mother cell walls or on the daughter cells, or on both, these were separated on a Percoll gradient before the $\mathrm{LiCl}$ treatment. The daughter cells formed a relatively broad green band in the lower third of the centrifuge tube $\left(\varrho=1.083 \mathrm{~g} \cdot \mathrm{cm}^{-3}\right)$, whereas the mother cell walls were concentrated in a thin (approx. $1 \mathrm{~mm}$ ) colourless band in the upper third $\left(\varrho=1.017 \mathrm{~g} \cdot \mathrm{cm}^{-3}\right)$. Upon inspection by light- and electron microscopy, the mother cell walls were found to resemble in size and shape those of Chlorella fusca 211-8p (Fig. 21 in the work of Atkinson et al. 1972). When the cell-wall-lytic activity derived from the two fractions was tested, the greater part $(70-85 \%)$ turned out to originate from the young cells and a smaller part (15-30\%) from the mother cell walls.

The activities obtained from the two sources eluted on a Bio-Gel P-100 column in the same volume corresponding to an apparent molecular weight of approx. $25 \mathrm{kDa}$ (Fig. 2). In one experiment, the three most active fractions from each run were pooled and tested at different $\mathrm{pH}$ values involving four buffer systems. A quite similar $\mathrm{pH}$ dependence of cell wall lysis became apparent: between $\mathrm{pH} 2$ and $\mathrm{pH} 9$ the activity hardly dropped below $50 \%$ of the maximum value and the ratios of activities in the $\mathrm{pH}$ range of each buffer were in close agreement (data not shown). This and the gel filtration data indicate that the lytic activities obtained from autospores and from mother cell walls might be qualitatively identical.

In the course of these experiments it was learned that the presence of Percoll during the $\mathrm{LiCl}$ treatment led to activities two- to severalfold higher. This seemed to be caused by the polyvinyl pyrrolidon coating of the Percoll particles, since with polyvinyl pyrrolidon (MW $\sim 350 \mathrm{kDa}$, Serva, Heidelberg, FRG) a similar stimulation could be achieved. As a consequence of this observation and the results above, for all subsequent enzyme preparations the $\mathrm{LiCl}$ treatment was carried out in the presence of Percoll (to be removed by centrifugation) and the separation of daughter cells and mother cell walls was omitted.

Purification and gel-electrophoretic analysis of the cell-wall-lytic activity. The data for two preparations using gel filtration for purification are given in Table 2. The amount of protein solubilized by the $\mathrm{LiCl}$ treatment was very low, corresponding 
Table 2. Data from two experiments on the purification of cell-wall-lytic activity from Chlorella fusca

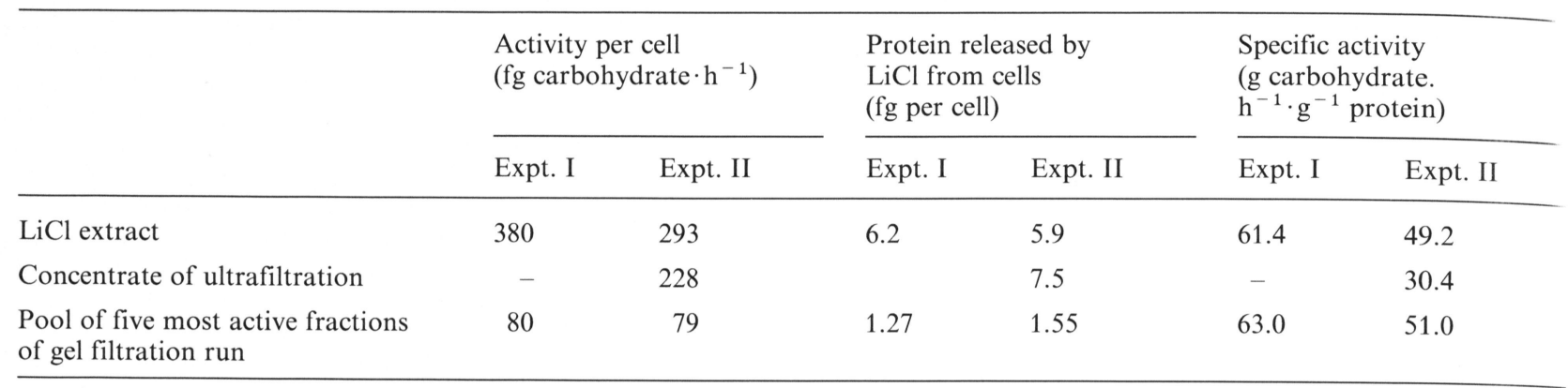

to only $0.1 \%$ of the cells' total protein. This figure is probably a maximal value, since traces of Percoll may have interferred in the protein assay; in a control experiment without Percoll a value of $0.05 \%$ of the total cell protein was obtained. No increase in specific activity was obtained after gel filtration since losses in total activity occurred for still unknown reasons.

In sodium dodecyl sulfate/polyacrylamide gel electrophoresis the unpurified $\mathrm{LiCl}$ extract gave rise to several bands with a main component of $44 \mathrm{kDa}$ molecular weight (Fig. 3 A, lanes 1 and 2). After gel filtration the number of bands was considerably reduced but the band at $44 \mathrm{kDa}$ was still dominating (Fig. 3 A, lane 3). For further purification the gel filtration step was preceded by a run on a chromatofocusing column. The $44 \mathrm{kDa}$ band correlated in its intensity with the enzymatic activity (Fig. 3 B, lanes 1 through 5); such a correlation was also seen in fractions eluted from a hydroxylapaptite column and from a carboxymethyl cellulose column (data not shown). The fuzzy material seen around 56 and $65 \mathrm{kDa}$ is considered to be an artifact, since it occurred also in blank lanes. On the chromatofocusing column the cell-walllytic activity eluted at $\mathrm{pH} 8.1-8.2$ indicating that a basic protein was responsible for it.

There is no experimentally based explanation yet for the discrepancy in the molecular weight obtained by gel filtration $(25 \mathrm{kDa})$ and by sodium dodecylsulfate/polyacrylamide gel electrophoresis $(44 \mathrm{kDa})$. Special interactions of the protein with the column material and/or an abnormal sodiumdodecylsulfate-binding capacity of the protein may lead to different apparent molecular weights.

Specificity towards exogenous substrates; products of enzyme action on $\beta-1,4-m a n n a n$ and isolated cell walls. The cell-wall-lytic enzyme did not react with laminarin and carboxymethyl cellulose (data not shown). Carbohydrate was solubilized, however, from $\beta$-1,4-D-mannan at rates comparable to those

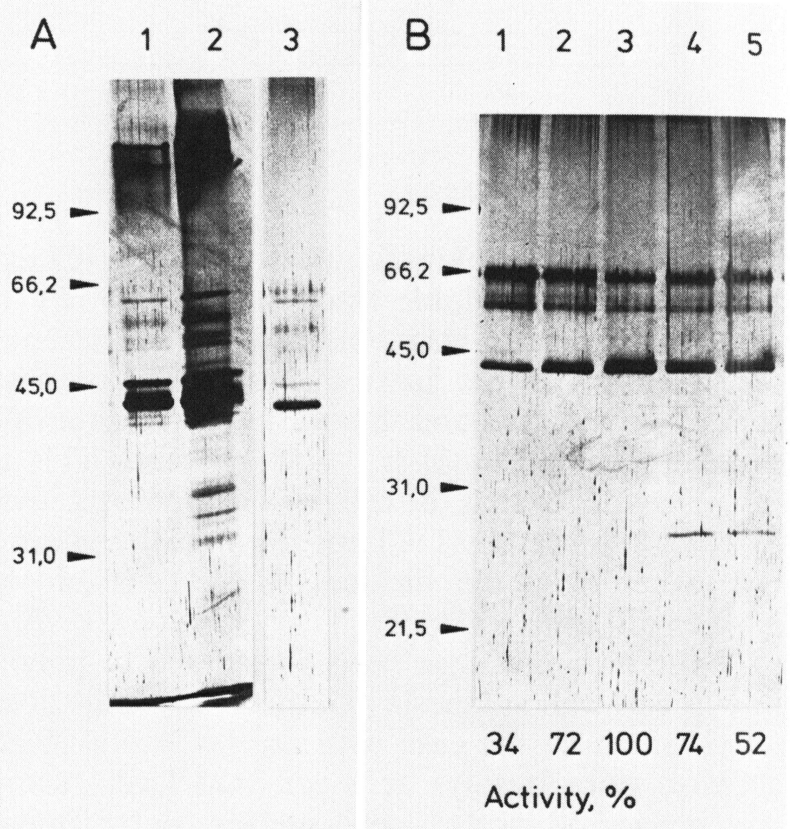

Fig. 3A, B. Sodium dodecylsulfate/polyacrylamide gel electrophoresis of material solubilized by $\mathrm{LiCl}$ from Chlorella fusca and purified to different extent. $\mathbf{A ~} \mathrm{LiCl}$ extract before (lanes 1 and 2) and after gel filtration (peak fraction, lane 3); the material applied to lanes 1 and 2 originated from $2.3 \cdot 10^{9}$ and 4.6 . $10^{9}$ cells, respectively. B Fractions from a gel filtration run preceded by a purification step on a chromatofocusing column. The activity of the peak fraction $(100 \%)$ corresponded to $1.6 \cdot 10^{-14} \mathrm{~g}$ carbohydrate $\cdot \mathrm{h}^{-1}$ per cell. At the side of each gel are indicated the molecular weights in $\mathrm{kDa}$ of marker proteins; from top to bottom: phosphorylase B, bovine serum albumin, ovalbumin, carbonic anhydrase, soybean trypsin inhibitor, lysozyme

of cell-wall lysis. These two activities eluted reproducibly together from the gel filtration column (Table 3) and also from a hydroxylapatite column (one experiment; data not shown). These findings indicate that the cell-wall-lytic enzyme was a mannanase. In highly purified preparations obtained from French-press extracts of C. fusca, the cellwall-degrading activity was always associated with 
Cable 3. Elution pattern of cell-wall-lytic activity, $\beta-1,4-\mathrm{D}-\mathrm{man}$ lanase and $\beta$-D-fucosidase from a Bio-Gel P-100 column. A $\mathrm{LiCl}$ extract from $6.4 \cdot 10^{10}$ cells was concentrated by ultrafiltraion and applied to the column. Activities of $100 \%$ were $5.4 \cdot 10^{-14}$ and $4.4 \cdot 10^{-14} \mathrm{~g}$ carbohydrate $\cdot \mathrm{h}^{-1}$ per cell for cell wall lysis and mannanase activity, respectively, and $1.9 \cdot 10^{-18} \mathrm{~mol} \cdot \mathrm{h}^{-1}$ per cell for $\beta$-D-fucosidase activity

\begin{tabular}{llll}
\hline Fraction & Cell-wall-lytic & Activity of & Activity of \\
No. & activity & $\beta-1,4-D-M a n n a n a s e$ & $\beta$-D-Fucosidase \\
& $(\%)$ & $(\%)$ & $(\%)$ \\
\hline
\end{tabular}

\begin{tabular}{llcl}
\hline 17 & - & - & 6.5 \\
18 & - & - & 33.5 \\
19 & 0 & 0 & 91 \\
20 & 0 & 0 & 100 \\
21 & 0 & 0 & 60.5 \\
22 & - & - & 20.5 \\
23 & - & 0 & 16 \\
24 & 0 & - & 15 \\
25 & 4.5 & 11 & 6.5 \\
26 & 30 & 45 & 4 \\
27 & 74 & 85 & 1 \\
28 & 93.5 & 101 & 0 \\
29 & 100 & 100 & 0 \\
30 & 84.5 & 83 & 0 \\
31 & 56 & 66 & 2 \\
32 & 30 & 34.5 & 0 \\
33 & 15.5 & 22.5 & 3.5 \\
34 & 5.5 & 8 & 0 \\
\hline
\end{tabular}

$\beta$-D-fucosidase activity (Walter 1984). In the present case, however, these two activities were clearly separated (Table 3); relatively low activities of $\beta$-Dglucosidase and $\beta$-D-mannosidase did not coelute with the cell-wall-lytic activity either (data not shown).

For analysis of the reaction products, cell walls or $\beta-1,4-\mathrm{D}-\mathrm{mannan}$ from ivory nut were incubated with a pool from the three purest fractions of a gel filtration run and the solubilized carbohydrate was chromatographed on thin-layer sheets. With cell walls and with $\beta$-1,4-D-mannan as substrates, most of the reaction products stayed at the origin. The degree of polymerization of these was estimated to be $\geqq 6$ by comparison with the migration behaviour of cello-oligosaccharides (cellobiose through cellopentaose). After recovery from the thin-layer and carbohydrate determination, this fraction was found to represent $75-85 \%$ of the total soluble carbohydrate and the fraction of smaller oligosaccharides $15-25 \%$. This percentual distribution was observed after both short $(15 \mathrm{~min})$ and long (180 min) incubation times when the carbohydrate of the substrate had been degraded by about 10 and $40 \%$, respectively.

In two experiments involving different enzyme preparations, the supernatant from a long incubation with cell walls was hydrolyzed and the mono- saccharides were analyzed by gas liquid chromatography; only mannose $(92-96 \%)$ and glucose $(4-8 \%)$ were detected. From these and from the thin-layer-chromatographic data it is concluded that the cell-wall-lytic activity is caused by an endo-mannanase.

\section{Discussion}

The simple method of salt treatment of the cells and mother cell walls followed by two columnchromatographic steps obviously provided a pure cell-wall-degrading enzyme, since the many cytoplasmic proteins were not contained in the salt extract. In contrast to the relatively high $\mathrm{LiCl}$ concentrations (3-6 mol$\left.\cdot 1^{-1}\right)$ required for removal of hydrolases from bacterial or higher-plant cell walls (Pooley et al. 1970; Huber and Nevins 1981), concentrations one order of magnitude lower were sufficient. Lithium chloride, therefore, probably did not act as a chaotropic reagent but rather participated in an ion exchange process at the surface of the cell walls.

Is the bound enzyme identical to the wall-degrading activity found previously in homogenates of mother cells (Loos and Meindl 1984; Walter 1984)? Pointing to a positive answer is the decrease in activity of the soluble enzyme(s) in the course of autospore release (Loos and Meindl 1984) and the simultaneous increase in activity of the bound enzyme. One might imagine that the enzyme becomes bound to the surface of the young cells and the mother cell wall after it has, somehow, been secreted and has degraded most of the mother cell wall from the inside; an attack on the autospore cell wall does not occur, probably because of its resistant sporopollenin-like outer layer (Atkinson et al. 1972). This view is strengthened by the absence of significant cell-wall-degrading activity in the culture medium (Loos and Meindl 1984; Walter 1984). An analogous situation seems to exist in yeast, where at the beginning of ascospore formation the decrease in activity of a specific glucanase is accompanied by a temporary increase in the same enzyme activity in a cell-wall-associated form (Hien and Fleet 1983).

That the bound and soluble enzymes are identical is also indicated by their similar gel filtration profiles and by the coelution of $\beta$-1,4-mannanase activity in both cases (cf. Loos and Meindl 1984). Also the molecular weights, as determined by sodium dodecyl sulfate/polyacrylamide gel electrophoresis, are in close agreement (compare Walter 1984). Furthermore, the bound enzyme degrades isolated cell walls in an endo-fashion, as was found 
for the highly purified soluble enzyme by Walter (1984). A point of disagreement, however, is the absence of any $\beta$-D-fucosidase activity in the bound cell-wall-lyzing enzyme (Table 3 ), whereas these two activities could not be separated from each other in the experiments of Walter (1984). The reason for this descrepancy is not clear.

The cell-wall-lytic enzyme degraded isolated cell walls to soluble products containing chiefly mannose $(92-96 \%)$ and some glucose $(4-8 \%)$; the share of glucose, however, in the sugar pattern of intact cell walls is greater $(26 \%$ glucose, $72 \%$ mannose; Loos and Meindl 1982). For the residual wall, therefore, an even higher percentage of glucose would be expected, unless other enzymes e.g. glucanases - effect a further degradation.

This work was supported by the Deutsche Forschungsgemeinschaft.

\section{References}

Atkinson, Jr. A.W., Gunning, B.E.S., John, P.C.L. (1972) Sporopollenin in the cell wall of Chlorella and other algae: Ultrastructure, chemistry, and incorporation of ${ }^{14} \mathrm{C}$-acetate, studied in synchronous cultures. Planta 107, 1-32

Blumreisinger, M., Meindl, D., Loos, E. (1983) Cell wall composition of chlorococcal algae. Phytochemistry 22, 1603-1604

Dubois, M., Gilles, K.A., Hamilton, J.K., Rebers, P.A., Smith, F. (1956) Colorimetric method for determination of sugars and related substances. Anal. Chem. 28, 350-356
Hien, N.H., Fleet, G.H. (1983) Variation of $(1 \rightarrow 3)-\beta$-glucanases in Saccharomyces cerevisiae during vegetative growth, conjugation, and sporulation. J. Bacteriol. 156, 1214-1220

Huber, D.J., Nevins, D.J. (1981) Partial purification of endoand exo- $\beta$-D-glucanase enzymes from Zea mays L. seedlings and their involvement in cell-wall autohydrolysis. Planta 151, 206-211

King, J., Laemmli, U.K. (1971) Polypeptides of the tail fibres of bacteriophage T4. J. Mol. Biol. 62, 465-477

Kuhl, A. (1962) Zur Physiologie der Speicherung kondensierter anorganischer Phosphate in Chlorella. In: Beiträge zur Physiologie und Morphologie der Algen, pp. 157-166, Deutsche Botanische Gesellschaft, ed. Fischer, Stuttgart

Loos, E., Meindl, D. (1982) Cell wall composition of Chlorella fusca. Planta 156, 270-273

Loos, E., Meindl, D. (1984) Cell wall-lytic activity in Chlorella fusca. Planta 160, 357-362

Matile, Ph. (1975) The lytic compartment of plant cells. (Cell biology, monographs, vol. 1) Springer, Wien New York

Moore, S. (1968) Amino acid analysis: aqueous dimethyl sulfoxide as solvent for the ninhydrin reaction. J. Biol. Chem. 243, 6281-6283

Morrissey, J.H. (1981) Silver stain for proteins in polyacrylamide gels: a modified procedure with enhanced uniform sensitivity. Anal. Biochem. 117, 307-310

Pooley, H.M., Porres Juan J.M., Shockman, G.D. (1970) Dissociation of an autolytic enzyme-cell wall complex by treatment with unusually high concentrations of salt. Biochem. Biophys. Res. Commun. 38, 1134-1140

Walter, J. (1984) Zellwandabbau bei Chlorella fusca (Shihira et Krauss): Isolierung und Charakterisierung der beteiligten Enzyme und deren Beeinflussung durch zelleigene Effektoren. Dissertation, Aachen (FRG) 1984

Received 29 June; accepted 1 August 1985 